ȘTEFAN BAGHIU ${ }^{1}$

\title{
THE SOCIALIST REALIST NOVEL IN ROMANIA BETWEEN 1948 AND 1955. NOVELISTIC GENRES AND SUBGENRES
}

There are two reasons for my apparently exhaustive title. First of all, my intention in this article is to offer a panorama of the socialist realist novel by considering all the novels published in Romanian and on Romanian territory between 1948 and 1955, tracing the first stage of the socialist realist novel in Romania (with its specific rigors and cultural policies). Although the two phases of socialist realism (1948-1955 and 1956-1964) have already been identified in literary historiography ${ }^{2}$, my rationale for separating them has to do with the dynamic of novel translation and the possibility to differentiate between the two stages in a concrete, affirmative way, through the translation programs discovered in the quantitative analysis of imports. Namely, between 1948 and 1955, Russian and Soviet translations dominated the Romanian landscape over Western translations, while between 1956 and 1964 the two poles of the Cold War were balanced $^{3}$.

This is why I will primarily discuss the subgenres of the socialist realist novel in the period when it manifested fully, both in translation and local production, because this is the only time when the socialist realist novel presents no exceptions. Of course, Proletkult ${ }^{4}$ literature will continue to be a part of novel production until the end of the communist regime, but this first period is fit for classification because it contains almost no other type of novel. Secondly, I intend to map all the subgenres proposed under the broader umbrella of the literary current, tracking the

\footnotetext{
${ }^{1}$ This work was supported by a grant of the Romanian Ministry of Education and Research, CNCSUEFISCDI, project number PN-III-P1-1.1-TE-2019-0946, within PNCDI III.

${ }^{2}$ See a synthesis of this periodization as put forward by Eugen Negrici and others in Andrei Terian, Critica de export. Teorii, context, ideologii [Export Criticism. Theories, Contexts, Ideologies], București, Muzeul Național al Literaturii Române, 2013, p. 172.

${ }^{3}$ Ştefan Baghiu, "Strong Domination and Subtle Dispersion: A Distant Reading of Novel Translation in Romania", in Maria Sass, Ștefan Baghiu, and Vlad Pojoga (eds.), The Culture of Translation in Romania, Berlin, Peter Lang, 2018, pp. 63-84.

${ }^{4}$ I use this term only as a superficial and general label, although its use in the Romanian context has been convincingly confronted by Sanda Cordoș and others. See Sanda Cordoş, Literatura intre revoluţie şi reacţiune. Problema crizei în literatura română şi rusă a secolului XX [Literature between Revolution and Reaction. The Issue of Crisis in Romanian and Russian Literature of the 20th Century], second edition, Cluj-Napoca, Biblioteca Apostrof, 2002. See also Cosmin Borza, "Trei concepte 'socialiste': realismul, postmodernismul, estetismul" ["Three 'Socialist' Concepts: Realism, Postmodernism, Aestheticism”], Caietele Sextil Pușcariu, 2015, 2, pp. 535-541.
} 
same logic I had outlined regarding translation: namely that, far from being defined by mono production in terms of theme and genre, socialist realism is as diverse as it is ideologically rigid. Therefore, I will consider the concept of socialist realism to be sufficiently broad for the entire production of the period, characterised by its programmatically progress-oriented literature, but not coherent enough to serve as a novelistic genre or subgenre, since socialist realism - in my reading - is rather an attitude for writers to aspire, rather than a formula.

\section{Internal Contradictions and Problematic Definitions}

This paper aims to survey some of the key elements of the socialist realist novel and to explain why it is, in fact, an umbrella term for multiple subgenres, seeking uniformity only in its desire to connect literature with a more or less coherent ideological programme. More or less coherent because, in spite of the theses formulated in literary historiography, according to which socialist realism represents the brutal standardization of creative principles, many recent studies have shown that this standardization was primarily accomplished along the way, through various mechanisms of verification and critique and in accordance with often changeable strategies.

In this sense, perhaps the most interesting case analyzed by recent literary criticism - and the best example for the theory of dogmatic instability in socialist realism - is Marin Preda's novella Ana Roșculeț. As shown by Alex Goldiș, even certain attempts at compliance with the new writing regime of the socialist realist period met with strong criticism within the literary field ${ }^{5}$. The situation is extremely interesting for the exposure of the creative process in socialist realism, a process which implied the complicity of authors and literary critics even in the first stages of conceiving the episodes of the story (as I will prove in this article) and which actually abolished the "finite" nature of the socialist realist literary work. In short, in Goldiș's words, "although the story condenses almost all of the socialist realist clichés, seeming to respond to the deepest desires of party politics, it has been, however, criticized from strong ideological viewpoints". Horia Bratu, one of its critics, objects to the depiction of the protagonist's enjoyment of her holiday even after her 'enlightenment': "how can the worker enjoy her holiday as free, personal time, when she has already begun her radical transformation through work and communion with the others?"' Goldis asks ironically, noticing the subtlety of the criticism against a text meant to be perfectly congruent with the official ideological view. The case is not singular and, as shown by Goldiș, the phenomenon is symptomatic for the local (and, perhaps, transnational) profile of the current: "those who tried to apply the norms of socialist realism to literature

\footnotetext{
${ }^{5}$ See Alex Goldiș, "Din clasicii realismului nostru socialist. Marin Preda, Ana Roșculeț" ["Reading the Classics of our Socialist Realism. Marin Preda, Ana Roșculeț"], Vatra, 2008, 5, pp. 36-38.

${ }^{6}$ Ibidem, p. 36.
} 
didn't come up against ideology, as most would believe, but against literature itself, which almost always tells a very different story from what its authors meant to say"7. In short, in spite of all the casual descriptions of the specificity of the socialist realist novel, its main profile was actually given by a set of conventions which required ample debates and real-time tuning.

A second problem stems from the first: even if they were governed by a literary 'recipe' or a 'thesis', the socialist realist works which remain valid until today and which were published or proposed for publication in the socialist realist period are now viewed as subversive. These works were not designed as such from the beginning, but literary historiography has seen most of them as forms of escapism or as reactions to the official ideology. However, more often than not, they were not reactions against the dogmatic style and were actually interpreted in this manner later on. Initially, most literary works complied with the logic of socialist realism and became incompatible with the ideological filter only upon publication.

Therefore, Eugen Negrici's theory that opens the famous series Literatura română sub comunism [Romanian Literature under Communism] which states that "directly or indirectly [in the process of a developing literature under a totalitarian regime], everything is a response, a reaction, a rebuff, a defensive, a desperate or inventive form of adaptation, a strategy for survival" 8 requires revisions like the ones discussed above. Not everything is "a response, a reaction, a rebuff" in socialist realism, because such a rebuff would have no value without a coherent programme of diverse forms of opportunism. It is true that the entire literature of the period is done (written, rewritten, eventually published) with the approval of political authority, but this does not mean that the mechanisms of approval were not complex ones. Here, of course, the problem is broader, going beyond Stalinism and including all the artistic pursuits that were perceived as acts of heroism after 1989, although in the context of their emergence they were easily acceptable officially.

In fact, after formulating his thesis about literature as reaction - that is, a few paragraphs later - Negrici himself describes "the writers whose conscience was not difficult to seduce and manipulate" and "the eternal intellectual opportunism". This nuance is also important, precisely because most of our contemporary critical bibliography depicts the socialist realist writer as either "manipulated" or "subversive". Post-communist anticommunism preferred a romantic, victimizing game in which the regime was one of occupation and found no local collaborators, only subtle dissidents. Otherwise, the emergence of certain masterpieces in the midst of socialist realism - Marin Preda's 1955 Moromeții [The Morometes] is the

\footnotetext{
${ }^{7}$ Ibidem.

${ }^{8}$ Eugen Negrici, Literatura română sub comunism [Romanian Literature under Communism], București, Editura Fundației Pro, 2006, p. 11.
} 
strongest example ${ }^{9}$ - would be inexplicable. Without further insistence on the matter, I think that reading the socialist realist novel merely for its subversive potential, or as a "survival" technique, is a major error which grants us no insight into the morphology of novelistic genres and subgenres and their function, into the dynamic of translation or into the internal geography and interferences within the Romanian literary polysystem of the Stalinist and post-Stalinist periods. Although it is comfortable (i.e. lazy) to describe a two-decade period using the same correlative, the reality in the field is completely different, which is noticeable even from a survey of the $\mathrm{DCRR}^{10}$ : socialist realism is as general a term as socialist novel or authoritarian fiction.

Another major issue in defining the current (and a possible "socialist realist" genre) has to do with an internal paradox of Soviet communism itself, explained by Hannah Arendt when discussing the nature of totalitarian regimes: while pleading for transformation, they actually need stability ${ }^{11}$ (or predictability, in the words of Evgeny Dobrenko and Natalia Jonsson-Skradol ${ }^{12}$ ). Thus, we are once again faced with the various problems related to placing socialist realism in its contemporaneity, since literary criticism has often pleaded that the term "realism" be replaced with "classicism", due to the rigors imposed on the depiction of reality. Although socialist realism coexists peacefully with the realism of the nineteenth and twentieth centuries (both in terms of translation and the revalorization of the canon of local critical realism), the central literary products of this period seem more rudimentary and excessively formalized ${ }^{13}$. In Critica in tranșee [Criticism in the Trenches], Alex Goldiș discusses this aporia of the current in the subchapter "Between modernism and socialist classicism", where he presents the recovery of a

\footnotetext{
${ }^{9}$ See more in Alex Goldiș, "The Ideology of Ruralism in the Thaw Prose: The Case of Marin Preda's Moromeții", in Ștefan Baghiu, Vlad Pojoga, and Maria Sass (eds.), Ruralism and Literature in Romania, Berlin, Peter Lang, 2019, pp. 95-105; Alex Goldiș, "Literary Interferences in Subversive East-European Prose under Communism”, in Maria Sass, Ștefan Baghiu, and Vlad Pojoga (eds.), The Culture of Translation in Romania, pp. 85-97.

${ }^{10}$ I use a tool put forward by the Romanian Academy, a complete dictionary of the Romanian novel: Dicţionarul cronologic al romanului românesc de la origini până la 1989 [The Chronological Dictionary of the Romanian Novel from Its origins to 1989] (DCRR), București, Editura Academiei Române, 2004.

${ }^{11}$ See Hannah Arendt, The Origins of Totalitarianism, London, Harvest Brace and Company, 1973.

${ }^{12}$ See Evgeny Dobrenko and Natallia Jonsson-Skradol (eds.), Socialist Realism in Central and Eastern European Literatures under Stalin. Institutions, Dynamics, Discourses, London, Anthem Press, 2018, p. 343: "Hannah Arendt remarked that one of the paradoxes inherent in totalitarian states is that, on the one hand, their professed veneration of transformations induces in them a deep-seated fear of stability and permanence, but on the other hand, for these regimes to function, their institutions require a certain degree of predictability and continuity".

13 Alex Goldiș, "Reading the Classics of our Socialist Realism", p. 37: "In fact, The Soviet critic Andrei Siniavski had noticed as early as the 1950s that the true name of socialist realism is 'socialist classicism', since Stalinist aestheticism, far from representing life as it really is, builds a utopia in the fashion of seventeenth century literature".
} 
"modern orientation" as a "value criterion" by the end of the $1950 \mathrm{~s}^{14}$. Thus, far from attempting to classify the novels of socialist realism according to their dogmatic value, which evidently turns the novelistic production into a monolithic one, I will map their thematic universe, i.e. their differences.

\section{The Rehabilitation of Serialized Publishing as a Form of Control}

The complete control that literary criticism must have over literary production determines certain technical aspects of the production process. First, the need to control the content of literary works generates an interesting phenomenon on the international stage, namely the complete publication of novels as fragments, prior to their emergence as printed books. This "habit" is recommended by the official press precisely so that the fragments can be perfected or purged of ideological "mistakes" before they become a finite product, that is before they become socialist realist. From this point of view, the creative process of socialist realist prose is similar to that of a production line with various quality checkpoints ${ }^{15}$.

This is why it is important to notice that socialist realism is based on the complicity between the writer and the literary critic as early as the production/ creation phase. And it is not only the official production of Romanian socialist realism that underwent this process, but also the well-known "exceptions": fragments from Marin Preda's Moromeții [The Morometes] were published in 1955 in Revista literară [The Literary Magazine], Contemporanul [The Contemporary] and Flacăra [The Flame ${ }^{16}$. The history of serialized publishing before the issue of the respective novel actually begins with the famous Descult [Barefoot] by Zaharia Stancu (of which more than six fragments appeared in Contemporanul and Flacăra in 1947 and 1948). It continues with Negura [The Mist] by Eusebiu Camilar (published in Viața românească [Romanian Life], Contemporanul, Scânteia [The Spark] or Flacăra in 1948 and 1949). Evadare [The Escape] by Alexandru Jar, a 1949 novel about the struggles of illegalists, had a first piece published in Flacăra in 1948, and Sfârșitul jalbelor [The End of Grievance], by the same author, appeared in 1950 in Viața românească, Flacăra, Contemporanul and Albina [The

\footnotetext{
${ }^{14}$ Alex Goldiş, Critica în tranșee. De la realismul socialist la autonomia esteticului [Criticism in the Trenches. From Socialist Realism to Aesthetic Autonomy], București, Cartea Românească, 2011, p. 57.

${ }^{15}$ In this regard, see the Eugen Luca quote, given by Alex Goldiș (Critica în tranșee, p. 12) from „Cu privire la sarcinile criticii literare" [On the duties of literary criticism] (Contemporanul, 1950, 185): "A. Fadeev argues that it is the responsibility of the critic to interfere even in the writer's creative process, providing the necessary suggestions when it is possible to undo certain faults and to develop positive aspects 'as he goes'. For this purpose, making a habit out of the serialized publishing of novels in literary magazines would be beneficial".

${ }^{16}$ See the most interesting case of the translation of The Morometes and other novels in this period to add to the process itself in Anca-Simina Martin, "The English Translation of Romanian Rural Novels in Communist Romania: Skopos Theory in Action”, in Ștefan Baghiu, Vlad Pojoga, and Maria Sass (eds.), Ruralism and Literature in Romania, pp. 81-95.
} 
Bee]. Fragments from Mitrea Cocor and Nada Florilor. Amintirile unui pescar cu undița [The Flower Bait. Memories of an Angler] by Mihail Sadoveanu (published in 1949 and 1950) appeared in Contemporanul and Adevărul literar și artistic [The Literary and Artistic Truth]. Similarly, Drum fără pulbere [Dustless Road] by Petru Dumitriu (1951), which presents the construction of the Danube-Black Sea Canal, was serialized in Viața românească and Femeia [The Woman].

One of the interesting cases, whose reception should be closely tracked right from their beginning as feuilleton prose, is Cella Serghi's Cad zidurile [The Walls are Falling] from 1950 (with fragments in Viața românească in 1938 and Revista Fundațiilor Regale [The Royal Foundations Magazine] in 1945), precisely because it was "verified" in the interwar period and published in the midst of socialist realism, focusing on the theme of "the universal Parisian Bohemia, with its cosmopolitan manner" (see "1950" in the DCRR).

\section{Subgenres}

As for the novel, it must be said from the start that the socialist realist novel is not always realist and, paradoxically, not even socialist realist. It is true that certain representational rules imposed as soon as 1932 in the Soviet Union and 1948 in Romania were used as compositional grids for the central productions of the period, but socialist realism constitutes, above anything else, an attempt at the ideological systematization of a diverse thematic area.

It is this systematization that is the cause of the apparent uniformity of socialist realist prose, not the fact that the literature itself had the characteristics of a selfsufficient subgenre. In fact, a few preliminary aspects must be discussed before the categorization of novelistic subgenres in socialist realism. First, the fact that the thematic diversity of the socialist realist novel produced on Romanian territory after WWII is indebted to the thematic diversity of the Soviet socialist realist novel and of other literatures annexed by the socialist realist programme. According to Rossen Djagalov, this programme "tried to organize 'the progressive forces' of world literature through international writers' organizations, writers' congresses, frequent bilateral visits, multilingual literary magazines and massive translation initiatives" between global literature and Moscow and inevitably diversified the thematic content of socialist realism ${ }^{18}$. I have recently discussed this phenomenon with a

\footnotetext{
17 Rossen Djagalov, "Literary Monopolists and the Forging of the Post-World War II People's Republic of Letters", in Evgeny Dobrenko, Natalia Jonsson-Skradol (eds.), Socialist Realism in Central and Eastern European Literatures, p. 25.

${ }^{18}$ Ibidem, p. 26: "What, more than anything, held the post-war People's Republic of Letters together - besides the unevenly practiced doctrine of socialist realism or the relatively homologous structures of writers' unions and publishers subordinated to Party authorities of each Soviet-bloc state - was a very small number of representative writers, or monopolists, as we shall call them, such as Ilya
} 
focus on fantasy and SF novel translations, so I will not reiterate the argument ${ }^{19}$. Especially when it comes to "conditional employment" (using Mihai Iovănel's terminology), genre fiction was a real and important presence in the literary field of socialist realism ${ }^{20}$.

Besides this institutional dynamic, however, there is the concrete problem of novelistic subgenres in the age of socialist realism. I will move beyond Susan Rubin Suleiman's useful analysis in Authoritarian Fictions. The Ideological Novel as a Literary Genre, which coins authoritarian fiction as a descriptive concept "novels with a clear ideological message - novels that seek, through the vehicle of fiction, to persuade their readers of the 'correctness' of a particular way of interpreting the world" ${ }^{21}$. Suleiman puts forward the famous concept of the roman $\grave{a}$ thèse, which "proclaims its own status as both overtly ideological and as fictional". Eventually, this concept could apply to almost all the novels produced during socialist realism, so it is of no use here, since it can be found anywhere. A novelistic genre cannot be established solely through its theses. It requires that we take its world/ universe into consideration as well. To create coherent categories for authoritarian fiction and its novelistic genres and subgenres during Romanian socialist realism, we need a more didactic approach than is usually recommended, so that my classification may further be found reductionist.

But this is where we find ourselves at the moment: far from requiring more theory, there is an urgent need for classification. In the following, I propose a classification of the Romanian socialist realist novel, based on the analysis of the "archive": the industrial novel, the rural novel, the novel for children and the youth, the historical and the adventure novel, the war novel, the fantasy/ SF novel. Of course, I have eliminated superstructure categories (the social novel, the psychological novel, etc.) precisely because all socialist realist novels are social through their emphasis on progress, and none is psychological (with the exception of minor psychological slips, promptly disciplined in the literary press of the time). Besides these, there are also some sentimental and autobiographical novels.

In short, this is the landscape of the Romanian socialist realist novel between 1948 and 1955, beyond its general roman à thèse label.

\footnotetext{
Ehrenburg, Jarosław Iwaszkiewicz, Anna Seghers, Mihail Sadoveanu, György Lukács, Nâzim Hikmet, Louis Aragon, Pablo Neruda, Jorge Amado, Go Mo Zho, and Howard Fast, who served as the liaisons between their national literatures and the Moscow centre".

19 Ștefan Baghiu, "The Functions of Socialist Realism: Translation of Genre Fiction in Communist Romania”, Primerjalna književnost, 42, 2019, 1, pp. 119-132.

20 Mihai Iovănel, "Mobile Frontiers: Instrumentations of Paraliterature in Modern Romanian Literature (1878-2018)", Transylvanian Review, 28, 2019, 1, pp. 73-82.

21 Susan Rubin Suleiman, Authoritarian Fictions. The Ideological Novel as a Literary Genre, Princeton, Princeton University Press, 1993, p. 1.
} 


\section{The Industrial Novel}

In the wake of the communist national industrialization, the socialist realist Romanian novel often turns into a constant plea for automation and begins to look at life in a factory or a plant. The first industrial novel published during socialist realism was written by Cella Serghi and appeared in 1950: Cântecul uzinei [The Plant Song]. However, it was merely a novel "heading towards socialist realism", even from the point of view of its contemporary literary critics. It is essential to note that, although the author had been present in Femeia [The Woman] (edited by the Romanian Democratic Women's Union), she had been described as a representative of "the formalist-cosmopolitan formula" by Cornel Regman in his famous 1949 article, „Naționalism și cosmopolitism în cultura română” ["Nationalism and Cosmopolitanism in Romanian Culture"] ${ }^{22}$ and later rehabilitated by Petru Comarnescu in 1950, after the issue of Cad Zidurile [The Walls are Falling], seen as a representation of "the transformative process of a heroine within the fictional world, as well as of Cella Serghi herself, who goes from a bourgeois psychologism to critical realism and, eventually, even progressive realism, which will help her achieve socialist realism in future works"23.

There is, thus, a progression (critical realism, progressive realism, socialist realism) noticeable in the allowed evolution of the genre. The industrial novel had had sporadic precedents on Romanian territory, especially due to Bovaric literary projects like Americana îndrăgostită [The American in Love] by Vasile Pop (1920), about work migration in American factories ${ }^{24}$.

Moreover, as shown by Andrei Terian, there is a whole set of novels on the subject of oil exploitation and deforestation (Mihail Sadoveanu with Nopțile de

\footnotetext{
22 Cornel Regman, "Naționalism și cosmopolitism în cultura română" [Nationalism and Cosmopolitanism in Romanian Culture], Almanahul literar [The Literary Almanac], 1949, 1, in Eugen Simion (ed.), Cronologia vieții literare românești. Perioada postbelică: 1944-1969 [The Chronology of the Literary Life. The Postwar Period: 1944-1969], vol. IV (1949-1950), București, Muzeul Național al Literaturii Române, 2011, p. 210: "The aestheticist-formalists of bourgeois criticism, shaped by French culture, become ecstatic in the face of all such innovations, theorizing the classics' lack of actuality (E. Lovinescu), the necessity of 'urbanization', the need for Western themes in art - the formalist-cosmopolitan formula whose results can be witnessed in the novels of the 'Romanian city' (the authoresses in Lovinescu's literary circle: Cella Serghi, Ioana Postelnicu, Sorana)".

${ }^{23}$ Petru Comarnescu, "Romanul clarificării unor conştiinţe, Cad zidurile" ["A Novel of Clarified Consciences, The Walls are Falling], Universul [The Universe], 1950, 7, in Eugen Simion (ed.), Cronologia vieții literare, vol. IV (1949-1950), p. 253.

${ }^{24}$ Vasile Pop, Americana îndrăgostită [The American in Love], București, Editura Librăriei Socec, 1920. See Ștefan Baghiu et alii, The Digital Museum of the Romanian Novel: 1900-1932, Sibiu, Complexul Național Muzeal ASTRA, 2020, http://revistatransilvania.ro/mdrr1900-1932. See more on the genres of the interwar period in Andrei Terian, Daiana Gârdan, Emanuel Modoc, Cosmin Borza, Dragoș Varga, Ovio Olaru, and David Morariu, "Genurile romanului românesc (1900-1932). O analiză cantitativă" [“The Genres of the Romanian Novel (1900-1932). A Quantitative Analysis”], Transilvania, 2020, 10, pp. 53-64.
} 
sânziene [Midsummer Nights] and Cezar Petrescu with Aurul negru [Black Gold]), which connect the social mining novel with postwar magical realism ${ }^{25}$. Of course, although novels like De două mii de ani [For Two Thousand Years] by Mihail Sebastian include scenes set on oil sites, they cannot be seen as industrial novels, since the theme is only episodic. As for the depiction of mining in the precommunist industrial novel, there are a few examples, such as Carol Ardeleanu's 1933 Viermii pământului [Earth Worms], rediscussed as "popular" achievements during socialist realism ${ }^{26}$. The specificity of the socialist realist industrial novel lies with the prior documentation of the analyzed subject. Although often ideologically directed, the reality within the novel must conform to the reality "in the field", given the fact that the boundaries between fiction and reality were erased in this period. In short, the industrial novel both documents and reckons up the regime's achievements.

As for plants, factories and hydropower stations, Oțel și pâine [Steel and Bread] (1951) by Ion Călugăru describes the Iron and Steel Enterprise in Hunedoara, Cumpăna luminilor [Balance of Lights] (1952) by Nicolae Jianu describes the activity of the Semenic hydropower station, In oraşul de pe Mureș [In a city upon Muress] (1954) by Francisc Munteanu - that of the lathe factory in Arad, and Rădăcinile bucuriei [The Roots of Joy] (1954) by Ieronim Șerbu - the „Laminorul roșu" ["Red Rolling Mill”] factory. We could also add Pavel Dogaru (1955) by Dan Costescu. The category also includes Pădurea Poienari [The Poienari Forest] by Ioana Postelnicu, still interesting today especially due to its leading "female driller" protagonists, as well as mining novels (Nepoții lui Horea [Horea's Grandchildren] by Petru Vintilă, from 1951, Dragoș Viscol's 1953 Valea fierului [The Iron Valley]), Nicolae Deleannu's 1955 Nedeia din Poiana Miresei [The Bride's Glade], and Nicolae Jianu's 1955 Izvorul roșu [The Red Spring]).

Then, novels centred on infrastructure and construction can be added to the list. Ștefan Andrei wrote about the construction of a new residential neighborhood in Brașov in his 1952 Noul oraș [The New City]. Here, the most important subcategory is represented by novels about the Danube-Black Sea Canal construction, such as Petru Dumitriu's Drum fără pulbere [Dustless Road] (1951). Regarding this specific novel, Silviu Burcan's intervention is most interesting, as it mentioned "certain drawbacks in its reflection of the truth of life", which were later exposed by "the party press and the readers" 27 (true power-masses) ${ }^{28}$.

\footnotetext{
25 Andrei Terian, "Extractivism, or the Birth of Magical Realism as World Literature", Textual Practice, 2021, https://www.tandfonline.com/doi/abs/10.1080/0950236X.2021.1886710. Accessed March 2, 2021.

${ }^{26}$ H. Zalis, "Clasa muncitoare în literatura dintre cele două războaie" ["The Working Class in Interwar Literature"], I-II, Tribuna, 1959, 28-29, p. 3.

${ }^{27}$ See Eugen Simion (ed.), Cronologia vieții literare, vol. V (1951-1953), p. 378.

${ }^{28}$ Evgeny Dobrenko, “The Disaster of Middlebrow Taste, or, Who 'Invented' Socialist Realism?”, in Thomas Lahuesn and Evgeny Dobrenko (eds.), Socialist Realism Without Shores, Durham, Duke University Press, 1997, pp. 135-165.
} 


\section{The Rural Novel}

As for the rural novel, it took only two decades for socialist realism to reach the production of the entire interwar period. According to Cosmin Borza, between 1945 and 1964 the same number of novels was published as between 1919 and 1944 (and four times as many in both intervals than between 1896 and 1918) ${ }^{29}$. However, the best period by far for the production of rural novels is 1965-1989, when twice as many are published than in the first socialist realist phase. Borza shows that "the first socialist-realist novel is published already in 1945 (Marin Iorda's Oameni în cătușe de aur [People in Golden Handcuffs], whereas the series of novels treating collectivization opens with Ion Istrati's Grâu infrățit [Brotherly Wheat] (1950) and Eusebiu Camilar's Temelia [The Foundation] (1951, published one year previously as a feuilleton). This marks the period of the genre's birth, either through the novelists' shift towards it or as absolute debut" ${ }^{\prime 30}$. I would propose a different approach than Borza's (which focuses on the canonical figures of the socialist realist rural novel). First, there are the collectivization novels. The theme emerges in poetry even before historical collectivization (it is the leitmotif of the famous 1947 Lazăr dela Rusca [Lazăr of Rusca] by Dan Deșliu), and it generates significant works in 1950 (Grâu infrățit by Ion Istrati), and 1951 (Temelia by Eusebiu Camilar, the first great novel of collectivization). Marin Preda's 1952 short story, Desfășurarea [The Unfolding] is also worth mentioning. A whole series follows, tackling the same themes: Trandafir de la Moldova [Moldavian Rose] by Ion Istrati (1952), Pâine albă [White Bread] by Dumitru Mircea (1952), Ogoare noi [New Fields] by Aurel Mihale (1953), and the 1954 Bărăgan by V. Em. Galan. The uprising novel is reactivated in autochthonous literature in Zorii robilor [The Slaves' Dawn] by V. Em. Galan (1950), Descult [Barefoot] by Zaharia Stancu (1948), Bijuterii de familie [Family Jewels] by Petru Dumitriu (1949), and Niculai Călărașul by C. Ignătescu (1953). The rural novel subgenre can also include Puntea din vale [The Valley Footbridge] by Al. Raicu (1948), Zilele vieții tale [The days of your life] - I, II, by Ion Pas (1949), Mitrea Cocor by Mihail Sadoveanu (1949), Orbecanii by Tiberiu Vornic (1950), Judecata [The Judgment] by Aurel Mihale (1952), Dulăii [The Hounds] by Zaharia Stancu, Ana Nucului by Remus Luca (1953), Mlaștina [The Marshland] by Silviu Podină (1953), Cronică de câmpie [Plain Chronicle] (1955) by Petru Dumitriu and Marșul miresei [Bride's March] (1955) by C. Ignătescu.

\footnotetext{
${ }^{29}$ Cosmin Borza, "How to Populate a Country. A Quantitative Analysis of the Rural Novel from Romania (1900-2000)", in Ștefan Baghiu, Vlad Pojoga, and Maria Sass (eds.), Ruralism and Literature in Romania, pp. 21-40. For the larger picture of the production of the Romanian novel see Andrei Terian, "Big Numbers. A Quantitative Analysis of the Development of the Novel in Romania", Transylvanian Review, 28, 2019, 1, pp. 55-71.

${ }^{30}$ Ibidem.
} 
By the end of the period, a new type of rural novel is devised where realism doesn't generate consciousness within the rural world, but outside of it, and the technicians and engineers who enter this space become central characters: Floarea vieții [The Flower of Life] by Aurel Mihale or Aventură în Lunca Dunării [Adventure in the Danube Delta] by Mihail Sadoveanu (both from 1954). In the latter, the intellectual protagonist visits an "agricultural state household" and "takes part in the capture of a criminal, Mustăcilă, a corrupt administrator in charge of the household's piglets and a friend of the enterprise director, thus getting to know the new realities of the village" ("1954" in the DCRR). The Danube fishermen novel is also extremely important within the rural genre, as it exposes the poverty and backwardness of Romania's southern regions ${ }^{31}$ : Soarele răsare în Deltă [The Sun Rises over the Delta] by Vladimir Colin (1951), La malul apelor [By the Water] by Florin Petrescu (1953) or Aventură în Lunca Dunării by Mihail Sadoveanu (1954) are such critical narratives. Besides these rural novels and those concerning Danube fishermen, some archaic civilization novels also emerge during the socialist realist phase, such as Mihail Sadoveanu's 1948 Păuna Mică and his 1950 Nada Florilor [The Flower Bait], or In valea Marelui Fluviu [The Valley of the Great River] by Felix Aderca, from 1955. The novels reproduce the dominant ideas of the period within agricultural and harvest communities, either directly in the Neolithic Age (Aderca) or in isolated communities that discover socialism instinctively, by withdrawing from society.

\section{The Historical Novel, the War Novel, the Social Fresco}

These subgenres are often difficult to distinguish from the industrial, rural or children and youth novels because their characteristics often overlap. What sets them apart, however, is an obsession with the past or contemporaneity as seen in the process of exposing current historical events.

Thus, in terms of actuality-based political novels we have examples like Veneau de pretutindeni [From High and Low] by Mihail Florescu (1948) (about the battles between the Germans and the French during the Occupation) and Negura [The Mist] by Eusebiu Camilar (1949) (which uses the example of Cezar Petrescu's Intunecare [Gathering Clouds] about Romania's involvement in WWI, describing events from WWII).

Along these, there are novels about the war and illegalist struggles such as Inimă de tânăr [A Young Heart] (1948) by A. Stancu, about the Spanish civil war of 1936, Evadare [The Escape] (1949) by Alexandru Jar, about the illegalist fight against the Germans, Vițelul de aur [The Golden Calf] (1949) by Ieronim Șerbu,

\footnotetext{
${ }^{31}$ I tried to draw a parallel between these novels about the poor Romanian South and other narratives about the Global South through the lens of translation in Ștefan Baghiu, "Translating Hemispheres: Eastern Europe and the Global South Connection through Translationscapes of Poverty", Comparative Literature Studies, 56, 2019, 3, pp. 487-503.
} 
about business opportunism during the war, condemning the exploitation of military conflict for personal financial gain, Scântei în beznă [Sparks in the Dark] (1950), Clocote [Tumult] (1954) by A.G. Vaida, O poveste simplă [A Simple Story] (1955) by Alexandru Jar, once again about illegalists. Another interesting case is that of Sfârşitul jalbelor [The End of Grievance] (1950) and Marea pregătire [Great Preparations] (1952) by Alexandru Jar, both of which present the Grivița strikers and the 1933 uprisings.

As for the historical novel about past events, the genre abounds in local figures meant to reorganize the existent heroic heritage: in 1953, C. Ghiban publishes Flăcăul din Binținți [The Binținți Lad] about Aurel Vlaicu; in 1951 I.D. Mușat writes Răscoala iobagilor [The Serf Uprising] about Gheorghe Doja; likewise, Camil Petrescu publishes Un om intre oameni [A man among men] (1953) about Nicolae Bălcescu, Dumitru Almaș - Neculai Milescu spătarul [Nicolae Milescu, the sword bearer] (1954) (which can also be seen as children or youth literature, as most of Almaș's writing), Cezar Petrescu - Ajun de revoluție 1848 [Revolutionary Eve, 1848] (1954) about the 1848 revolutionary figures, Radu Theodoru - Brazdă şi paloș [Plough and Sword] (1954) about Mihai Viteazul, and Mihnea Gheorghiu's Două ambasade [Two Embassies] (1955) about Dimitrie Cantemir. Then the list goes on with novels about WWI, like Pe văile Argeșului [Down the Argeș] by Sanda Movilă (1950) and Starea de asediu [The Curfew] by I. Ludo (1955). Social frescoes generally present the interwar and mid-war society, inter-party political conflicts and capitalist life (the latter especially as satire). Such social frescoes of bourgeois society include Painea inimii [Bread for the Heart] (1949) by Mihail Șerban, Cad zidurile [The Walls are Falling] (1950) by Cella Serghi (we have already discussed her evolution during socialist realism; the novel is not completely devoid of the psychological implications previously tested by the author), O alegere de pomină [The Infamous Choice] (1952) by Ioan Dorin, Bietul Ioanide [Poor Ioanide] (1953) by G. Călinescu, Domnul general guvernează [The General's Command] (1954), Gura de lup [Wolf Jaws] (1954) by I. Ludo, and Oameni de ieri, oameni de azi, oameni de mâine [People of Yesterday, People of Today, People of Tomorrow] (1955) by Cezar Petrescu.

\section{The Children and Youth Novel, the Fantasy/ SF Novel}

In its efforts to integrate socialist propaganda in the educational process, the Party considers children's literature to be a fundamental instrument for instilling scientific materialism in young minds. Thus, the socialist realist novel aimed at the youth pleads for two convergent elements: communitarianism/ socialism and science. As I have already analyzed these aspects in relation to novel translation during socialist realism, I will include a passage here: "A process of incorporation that was also visible in the communist states of Eastern Europe applied this time to their own literatures which were struggling to establish their local socialist literary canon. A good example in this regard is the debate over Ion Creangă, one of the 
most important Romanian nineteenth-century fiction writers. His alleged class struggle was put forward by socialist realist critic Al. N. Trestieni in 1946, who argues that his children's prose, drawing on folktales and fantasy, has depicted "under the guise of fantasy [...], genuine exploiter typologies" 32 .

Moreover, as shown by Mihai Iovănel in the case of fantasy and SF literature, "socialist realism, in a manner similar to its predecessor, Marxism, was based on a secular scientific foundation, and took much interest in positive disciplines such as physics, astronomy, and medicine, which serve as basis for science-fiction literature. Included in the program and supported by the system, by means of the then-highly popular "Colecția Povestiri științifico-fantastice" ["The Science-fiction Stories Series"], SF was one of the most efficient instruments for scientific promotion and ideological education in the $1950 \mathrm{~s}^{\prime 33}$. Besides these arguments explaining the relationship between fantasy or SF and socialist realism, one can also consider Darko Suvin's excellent analyses regarding the fact that "Soviet SF of the 1920s had [...] established a tradition ranging sociologically from facile subliterature to some of the most interesting works of 'highbrow' fiction" 34 . This is why the socialist realist period produced SF novels like Drum printre aștri [A Path among the Stars] (1954) by I.M. Ștefan and Radu Nor.

Among educational children and youth novels, a few notable examples are the imitative Pinocchio detectiv. Roman pentru copii [Pinocchio the Detective. A children's novel] (1948) by Mihai Axente (it must be said that the character Buratino initially belonged to the Soviet writer A.N. Tolstoy), Cei trei voinici [The Three Strong Men] (1948) by Alexandru Corodar, Chimiță R. Ilie, școlar și hoinar [Chimiță R. Ilie, Schoolboy and Wanderer] (1948) by Damian Stănoiu, which depicts the evolution of a peasant's son through education, Nodul pământului. Roman pentru tineret [The Centre of the Earth. A Novel for Youth] (1949) by Elena Mătase, Neghiniță (1949) by Cezar Petrescu, about an orphan in the wake of WWII bombing in Bucharest, Inimoșii [Kind People] (1953) by G. Iuteș, and even Tabăra din munți [The Mountain Camp] (1953) by Gellu Naum. The latter inaugurates a series of novels about juvenile vigilantes who capture criminals, which includes Marea bătălie de la Iazul Mic [The Great Battle of the Small Pond] (1953) by Octav Pancu-Iași or Cantemiriștii [The Cantemir Students] (1954) by Cella Serghi.

Travel (adventure) novels are also published, such as $M$-am făcut băiat mare [Becoming a Grown-up Boy] (1954) by Nicuță Tănase and Toate pânzele sus! [All

\footnotetext{
${ }^{32}$ See Eugen Simion (ed.), Cronologia vieții literare, vol. V (1951-1953), p. 186.

33 Mihai Iovănel, Ideologiile literaturii în postcomunismul românesc [Literary Ideologies in Romanian Postcommunism], București, Muzeul Național al Literaturii Române, 2014, pp. 165-166. See Iovănel's explanation of the link between "robots"/ "intelligent machines" and the rural novel in Mihai Iovănel, "Peasants and Intelligent Machines", in Ștefan Baghiu, Vlad Pojoga, and Maria Sass (eds.), Ruralism and Literature in Romania, pp. 117-128.

${ }^{34}$ Darko Suvin, Metamorphoses of Science Fiction. On the Poetics and History of a Literary Genre, New Haven and London, Yale University Press, 1979, p. 262.
} 
on Board!] (1954) by Radu Tudoran, as well as autobiographical novels: Lumina primăverii [Spring Light] (1948) by Ion Călugăru, about the coming of age of a socialist adolescent. Finally, Nicolae Minei writes a novel on racial segregation in the USA, Prietenul nostru Allan [Our Friend Allan] (1951), joining the general discourse of the period and the critique of colonialism and segregation.

\section{The Simultaneous Mutation}

At the end of this classification, I would like to briefly point out one aspect which has caught my attention regarding the novel of the first socialist realist stage. A sort of particular feeling can be noticed in novels published in 1954 and 1955 (that is, in the last year of the period), which has to do with the emergence of exceptions within each of the categories outlined above. With rural novels, the exception is Moromeții [The Morometes] by Marin Preda - I would also add Cronică de familie [Family Chronicle] by Petru Dumitriu. Here, the exception is ideological: this is the first novel where you don't find a concrete oppressor, but rather a suggested abstract oppression. In the same year, a film adaption appears, drawing on an office/ corporate novel (the terminology is exaggerated, of course, but this case was not far from the general corporate novel formula) and harshly criticising bureaucracy and its absurdities (Directorul nostru [Our Director]). Among novels set during WWII (war novels) we can count Străinul [The Stranger] by Titus Popovici, which represents a new level of the social fresco. In principle, all of these constitute a milestone, the moment when the first stage of socialist realism had come to an end.

\section{BIBLIOGRAPHY}

DCRR - Dicționarul cronologic al romanului românesc de la origini până la 1989 [The Chronological Dictionary of the Romanian Novel from Origins to 1989], București, Editura Academiei Române, 2004.

ARENDT, Hannah, The Origins of Totalitarianism, London, Harvest Brace and Company, 1973.

BAGHIU, Ștefan, POJOGA, Vlad, BORZA, Cosmin, COROIAN GOLDIȘ, Andreea, FRĂTEAN, Denisa, GÂRDAN, Daiana, GOLDIȘ, Alex, MODOC, Emanuel, MINCULETE, Iunis, MORARIU, David, OLARU, Ovio, SUSARENCO, Teodora, TERIAN, Andrei, VANCU, Radu, VARGA, Dragoș, Muzeul Digital al Romanului Românesc: 1900-1932 [The Digital Museum of the Romanian Novel: 1900-1932], Sibiu, Complexul Naţional Muzeal ASTRA, 2020, https://revistatransilvania.ro/mdrr1900-1932.

BAGHIU, Ştefan, "Strong Domination and Subtle Dispersion: A Distant Reading of Novel Translation in Romania", in Maria Sass, Ștefan Baghiu, and Vlad Pojoga (eds.), The Culture of Translation in Romania, Berlin, Peter Lang, 2018, pp. 63-84.

BAGHIU, Ștefan, "The Functions of Socialist Realism: Translation of Genre Fiction in Communist Romania”, Primerjalna književnost, 42, 2019, 1, pp. 119-132. 
BAGHIU, Ștefan, "Translating Hemispheres: Eastern Europe and the Global South Connection through Translationscapes of Poverty", Comparative Literature Studies, 56, 2019, 3, pp. 487-503.

BORZA, Cosmin, "How to Populate a Country. A Quantitative Analysis of the Rural Novel from Romania (1900-2000)", in Ștefan Baghiu, Vlad Pojoga, and Maria Sass (eds.), Ruralism and Literature in Romania, Berlin, Peter Lang, 2020, pp. 21-40.

BORZA, Cosmin, "Trei concepte 'socialiste': realismul, postmodernismul, estetismul" [Three 'Socialist' Concepts: Realism, Postmodernism, Aestheticism], Caietele Sextil Puşcariu, 2015, 2, pp. 535-541.

CORDOŞ, Sanda. Literatura între revoluţie şi reacţiune. Problema crizei în literatura română şi rusă a secolului XX [Literature between Revolution and Reaction. The Issue of Crisis in Romanian and Russian Literature of the 20th Century], second edition, Cluj-Napoca, Editura Biblioteca Apostrof, 2002.

DJAGALOV, Rossen, "Literary Monopolists and the Forging of the Post-World War II People's Republic of Letters", in Evgeny Dobrenko, Natalia Jonsson-Skradol (eds.), Socialist Realism in Central and Eastern European Literatures, pp. 25-37.

DOBRENKO, Evgeny, JONSSON-SKRADOL, Natallia (eds.), Socialist Realism in Central and Eastern European Literatures under Stalin. Institutions, Dynamics, Discourses, London, Anthem Press, 2018.

DOBRENKO, Evgeny. "The Disaster of Middlebrow Taste, or, Who 'Invented' Socialist Realism?", in Thomas Lahuesn and Evgeny Dobrenko (eds.), Socialist Realism Without Shores, Durham, Duke University Press, 1997, pp. 135-165.

GOLDIȘ, Alex, "Din clasicii realismului nostru socialist. Marin Preda, Ana Roșculeț" ["Reading the Classics of our Socialist Realism. Marin Preda, Ana Roșculeț"], Vatra, 2008, 5, pp. 36-38.

GOLDIȘ, Alex, "Literary Interferences in Subversive East-European Prose under Communism", in Maria Sass, Ștefan Baghiu, and Vlad Pojoga (eds.), The Culture of Translation in Romania, Berlin, Peter Lang, 2018, pp. 85-97.

GOLDIȘ, Alex, "The Ideology of Ruralism in the Thaw Prose: The Case of Marin Preda's Moromeții", in Ștefan Baghiu, Vlad Pojoga, and Maria Sass (eds.), Ruralism and Literature in Romania, Berlin, Peter Lang, 2019.

GOLDIȘ, Alex, Critica în tranșee. De la realismul socialist la autonomia esteticului [Criticism in the Trenches. From Socialist Realism to Aesthetic Autonomy], București, Cartea Românească, 2011.

IOVĂNEL, Mihai, "Mobile Frontiers: Instrumentations of Paraliterature in Modern Romanian Literature (1878-2018)", Transylvanian Review, 28, 2019, 1, pp. 73-82.

IOVĂNEL, Mihai, "Peasants and Intelligent Machines", in Ștefan Baghiu, Vlad Pojoga, and Maria Sass (eds.), Ruralism and Literature in Romania, Berlin, Peter Lang, 2020, pp. 117-128.

IOVĂNEL, Mihai, Ideologiile literaturii in postcomunismul românesc [Literary Ideologies in Romanian Postcommunism], București, Muzeul Național al Literaturii Române, 2014.

MARTIN, Anca-Simina, "The English Translation of Romanian Rural Novels in Communist Romania: Skopos Theory in Action", in Ștefan Baghiu, Vlad Pojoga, and Maria Sass (eds.), Ruralism and Literature in Romania, Berlin, Peter Lang, 2020, pp. 81-95.

NEGRICI, Eugen, Literatura română sub comunism [Romanian Literature under Communism], București, Editura Fundației Pro, 2006.

SIMION, Eugen (ed.), Cronologia vieții literare românești. Perioada postbelică: 1944-1969 [The Chronology of the Literary Life. The Postwar Period: 1944-1969], vol. IV (1949-1950), vol. V (1951-1953), București, Muzeul Național al Literaturii Române, 2010-2018.

SULEIMAN, Susan Rubin, Authoritarian Fictions. The Ideological Novel as a Literary Genre, Princeton, Princeton University Press, 1993.

TERIAN, Andrei, "Big Numbers. A Quantitative Analysis of the Development of the Novel in Romania", Transylvanian Review, 28, 2019, 1, pp. 55-71.

TERIAN, Andrei, "Extractivism, or the Birth of Magical Realism as World Literature", Textual Practice, 2021, https://www.tandfonline.com/doi/abs/10.1080/0950236X.2021.1886710. Accessed March 2, 2021.

TERIAN, Andrei, Critica de export. Teorii, context, ideologii [Export Criticism. Theories, Contexts, Ideologies], București, Muzeul Național al Literaturii Române, 2013. 
TERIAN, Andrei, GÂRDAN, Daiana, MODOC, Emanuel, BORZA, Cosmin, VARGA, Dragoş, OLARU, Ovio, MORARIU, David, "Genurile romanului românesc (1900-1932). O analiză cantitativă" ["The Genres of the Romanian Novel (1900-1932). A Quantitative Analysis"], Transilvania, 2020, 10, pp. 53-64.

ZALIS, H., "Clasa muncitoare în literatura dintre cele două războaie" ["The Working Class in Interwar Literature"], I-II, Tribuna, 1959, 28-29, p. 3.

\section{THE SOCIALIST REALIST NOVEL IN ROMANIA BETWEEN 1948 AND 1955. NOVELISTIC GENRES AND SUBGENRES (Abstract)}

This paper aims to survey some of the key elements of the socialist realist novel and to explain why it is, in fact, an umbrella term for more subgenres, seeking uniformity only in its desire to connect literature with a more or less coherent ideological programme. More, or rather, less coherent because, in spite of the theses formulated in literary historiography according to which socialist realism represents the brutal standardization of creative principles, many recent studies have shown that this standardization was primarily accomplished "along the way", through various mechanisms of verification and critique and in accordance with often changeable strategies. In the following, I propose a classification of the Romanian socialist realist novel based on the analysis of the "archive", into: the industrial novel, the rural novel, novels for children and the youth, the historical and adventure novel, the war novel and the fantasy/ SF novel. Besides these, there are also some sentimental, autobiographical or social fresco novels but, since their production was limited, I will discuss them very succinctly. In short, this is the landscape of the Romanian socialist realist novel between 1948 and 1955, beyond its general roman à thèse label.

Keywords: socialist realism 1948-1955, roman à thèse, ideology, Romanian novel, subgenres.

\section{ROMANUL REALIST-SOCIALIT DIN ROMÂNIA ÎNTRE 1948 ȘI 1955. GENURI ȘI SUBGENURI ROMANEȘTI (Rezumat)}

Articolul își propune să urmărească câteva dintre trăsăturile centrale ale aşa-numitului roman realistsocialist și să explice de ce noțiunea reprezintă, în fapt, un termen-umbrelă pentru mai multe subgenuri. Efectul utilizării sale este uniformizarea, de vreme ce singurul său scop este de a conecta literatura la un program ideologic mai mult sau mai puțin coerent. În ciuda tezelor formulate constant de istoriografia literară că realismul socialist reprezintă standardizarea brutală a principiilor creatoare, multe studii recente au demonstrat că respectiva standardizare a fost dobândită ,pe parcurs”, prin intermediul unor mecanisme de control diverse şi urmând strategii adeseori variabile. În consecinţă, articolul propune următoarea clasificare a romanului realist-socialist din România, bazată de analiza „arhivei” genului: romanul industrial, romanul rural, romanul pentru copii și tineret, romanul istoric și romanul de aventuri, romanul de război, respectiv fantasy/romanul științifico-fantastic. Dincolo de aceste tipologii, studiul ia în considerare și romanele sentimentale, autobiografice ori pe cele care implică fresce sociale, dar, având în vedere că productivitatea lor a fost restrânsă, analiza care le va viza va fi succintă. Pe scurt, acesta este tabloul sinoptic al romanului realist-socialist românesc dintre 1948 și 1955 problematizat în acest studiu, care va lua în considerare și componenta tezistă a literaturii realist-socialiste.

Cuvinte-cheie: realism socialist 1948-1955, roman cu teză, ideologie, romanul românesc, subgenurile romanului. 